\title{
"Problems of estimating the neutral interest rate: conclusions for Ukraine"
}

\begin{tabular}{ll} 
AUTHORS & $\begin{array}{l}\text { Bohdan Danylyshyn (i) } \\
\text { Ivan Bohdan (i) }\end{array}$ \\
\hline ARTICLE INFO & $\begin{array}{l}\text { Bohdan Danylyshyn and Ivan Bohdan (2021). Problems of estimating the neutral } \\
\text { interest rate: conclusions for Ukraine. Investment Management and Financial } \\
\text { Innovations, 18(3), 214-228. doi:10.21511/imfi.18(3).2021.20 }\end{array}$ \\
\hline DOI & http://dx.doi.org/10.21511/imfi.18(3).2021.20 \\
\hline RELEASED ON & Tuesday, 07 September 2021 \\
\hline RECEIVED ON & Sunday, 01 August 2021 \\
\hline ACCEPTED ON & Thursday, 02 September 2021 \\
\hline LICENSE & $\begin{array}{l}\text { This EY work is licensed under a Creative Commons Attribution } 4.0 \text { International } \\
\text { License }\end{array}$ \\
\hline JOURNAL & "Investment Management and Financial Innovations" \\
\hline ISSN PRINT & $1810-4967$ \\
\hline ISSN ONLINE & $1812-9358$ \\
\hline PUBLISHER & LLC “Consulting Publishing Company "Business Perspectives" \\
\hline FOUNDER & LLC “Consulting Publishing Company "Business Perspectives"
\end{tabular}

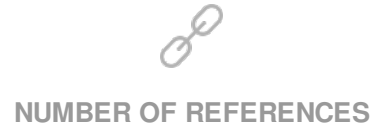

42

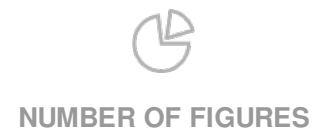

3
NUMBER OF TABLES

2

(C) The author(s) 2021. This publication is an open access article. 


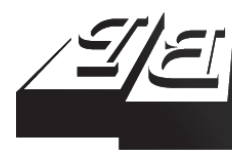

\section{BUSINESS PERSPECTIVES}

O

LLC "CPC "Business Perspectives" Hryhorii Skovoroda lane, 10, Sumy, 40022, Ukraine www.businessperspectives.org
Received on: $1^{\text {st }}$ of August, 2021 Accepted on: $2^{\text {nd }}$ of September, 2021 Published on: $7^{\text {th }}$ of September, 2021

(c) Bohdan Danylyshyn, Ivan Bohdan, 2021

Bohdan Danylyshyn, Doctor of Economics, Academician, Academician of the National Academy of Sciences of Ukraine, Professor, Department of Regional Studies and Tourism, National Economic University named after Vadym Hetman, Ukraine.

Ivan Bohdan, Ph.D. in Economics, Senior Scientific Associate, Senior expert of the Secretariat to the Council of the National Bank of Ukraine, Ukraine. (Corresponding author)

\title{
PROBLEMS OF ESTIMATING THE NEUTRAL INTEREST RATE: CONCLUSIONS FOR UKRAINE
}

\begin{abstract}
Estimation of the actual and projected level of the neutral interest rate is a central issue in the application of modern monetary theory in the practical context of monetary policy. Views on the role and key drivers of neutral interest rates have evolved over time in parallel with the development of the theory of capital, money, credit and economic growth. Therefore, the paper is aimed at generalizing methods for assessing the neutral interest rate for open economies with emerging markets and formulating recommendations for improving the existing methodological tools for estimating the neutral rate in Ukraine. To achieve this goal, theoretical sources, advisory and research materials of international organizations, central banks and statistical databases were analyzed. It is established that the key issue of the current discussion about the tools for estimating the level of neutral interest rates in countries with small open economies is the relationship between the effects of external and internal factors. The paper identifies the advantages and disadvantages of the method for estimating the level of the neutral rate on the basis of uncovered interest parity rule used by the National Bank of Ukraine within the semi-structural macroeconomic model. The expediency of methodological tools introducing into the practice of monetary regulation of Ukraine for estimating the neutral rate of Ukraine based on the Laubach-Williams approach has been proved with adaptation to the conditions of an open economy, which will consider cinternal factors of economic development - changes in potential GDP and savings.
\end{abstract}

\section{Keywords}

JEL Classification

\section{INTRODUCTION}

Measuring the neutral value of money is a key element in the decision-making process on monetary policy in the modern practice of regulating monetary relations. The relevance of this issue especially increased after the introduction into the practice of world central banks of an inflation targeting monetary regime, which involves the use of interest rates as the main instrument of monetary policy.

Positioning the level of the actual interest rate relative to its neutral level allows to assess the level of tightness of monetary policy, in particular, at certain stages of economic cycle. This allows for targeted adjustments of monetary policy depending on the central bank's mandate and current policy priorities.

The neutral rate concept was first proposed by Knut Wicksell in 1898, who defined it as the level of interest rate that balances the return on investment in financial assets with the return on non-financial investment projects.

The globalization and financialization of the late twentieth century have increased the role of external factors in economic processes. This led to the expansion of specification of neutral interest rate 
factors due to factors characterizing the investment attractiveness of the domestic economy for global investors.

After the global financial crisis of 2008-2009, a radical transformation of views on the role of the financial sector in economic processes took place. The tasks and functions of central banks in regulating the financial sector have been revised - the parameters of financial regulation of banking have been significantly tightened. Liberalization of international capital movements has ceased to be a key driver of domestic lending to the economy. In the development of tools for estimating and forecasting the neutral interest rate, this has led to greater emphasis on accounting for factors of domestic demand and domestic savings.

Another problematic aspect of the estimation of the neutral interest rate is the different nature of factors affecting its dynamics depending on the stage of market development of the economy. In countries with underdeveloped markets, low incomes and structural problems, the efficiency of monetary transmission is lower. This leads to a decrease in the penetration of international capital into processes in the real economy, reducing the influence of external factors of neutral interest rates in such economies.

In the aftermath of the 2009 global crisis, and especially during the 2020-2021 COVID-19 pandemic crisis, the tendency to modify the central bank's policy has intensified to reflect its role in sustainable and inclusive economic growth. This requires further changes in methodological approaches to estimating the neutral interest rate and its role in achieving the central bank's policy objectives.

Therefore, the purpose of this paper is to review the latest approaches to assessing the neutral value of money, summarize the key problematic issues of their application and formulate recommendations for improving the existing methodological tools in Ukraine for estimating the neutral interest rate.

\section{LITERATURE REVIEW}

Knut Wicksell, the author of the concept of a neutral (natural) interest rate, noted that the development of economic processes with an interest rate at a neutral level is balanced, since in such circumstances there is an optimal growth of bank lending with minimal inflationary risks (Wicksell, 1898 \& 1907). If the basic value of money corresponds to their neutral level, then the expansion of bank lending to the economy occurs solely in accordance with the growth of economic productivity and its purchasing power. The balanced growth in purchasing power and real GDP will minimize inflation risks. That is, a neutral rate balances the money supply (in the form of an increase in savings) with the money demand (in the form of real GDP and investment growth).

Ramsey (1928) proposed in the model of economic growth the equation of the equilibrium real interest rate as a function of the growth of per capita consumption and population.
The active application of the concept of neutral interest rate in the practice of planning the monetary policy of central banks began after the publication of Woodford (2003), who argued that the gap between actual and neutral interest rates is a key channel of influence of central bank policies on the economy. Woodford presented the concept of a neutral interest rate within the paradigm of the New-Keynesian economic model (Berg et al., 2006) as an interest rate that supports the conditions of general equilibrium in economy with flexible prices. He proved that the neutral interest rate is positively correlated with economic productivity and consumer shocks.

Laubach and Williams (2003) and Holston et al. (2016) proposed a methodology for estimating the neutral interest rate $\left(r_{t}^{*}\right)$, where its determining factors are changes in potential GDP and consumer intertemporal preferences. The first factor reflects productivity, while the second reflects savings. The Laubach and Williams model is based on New-Keynesian principles and contains two key equations. The first (Euler equation or IS curve) 
describes the relationship between the GDP gap (the gap between actual and potential GDP) and the interest rate gap (the gap between the actual and neutral interest rates). The second (Phillips equation) describes the relationship between the current inflation and the GDP gap, as well as expected and past inflation. The neutral rate is determined by solving a system of equations using the Kalman filter by the following equation:

$$
r_{t}^{*}=c \cdot y_{t}^{*}+z_{t}+\varepsilon_{t},
$$

where $y_{t}^{*}$ - change in potential GDP; $z_{t}$ - other factors, including changes in the consumer intertemporal preferences (between savings and consumption); $c$ - scaling parameter (from 0 to 1); $\varepsilon_{t}$ - shocks. Based on the presented concept, Laubach and Williams (2016) defined the neutral interest rate as "real short-term interest rate consistent with the economy operating at its full potential once transitory shocks to aggregate supply or demand have abated".

The Laubach and Williams approach is usually incorporated into the framework of semi-structural or structural dynamic stochastic general economic equilibrium (DSGE) models with a New-Keynesian microeconomic basis (Rucch, 2021). Such models allow one to substantiate the optimal economic policy based on fundamental economic laws.

Over the last decade, many researchers have extended various modifications of the Laubach and Williams approach (2003) to countries with emerging markets such as Brazil (Fonseca \& Muinhos, 2016), India (Behera et al., 2017), and Russia (Grafe et al., 2018), Poland (Stefanski, 2018), the Czech Republic (Hledik \& Vlsek, 2018), Turkey (Ogunc \& Batmaz, 2011), South Africa (Kuhn et al., 2019), and Peru (Humala \& Briones, 2011).

Since the approach proposed by Laubach and Williams is not elaborated enough for the application in a small open economy with free movement of capital, Hledik and Vlsek (2018) proposed a modified approach that takes into account the trend factor (devaluation) of the equilibrium real effective exchange rate (REER or $q_{t}^{*}$ ) to assess the effect of foreign investments in foreign currency:

$$
r_{t}^{*}=c \cdot\left(y_{t}^{*}+q_{t}^{*}\right)+\varepsilon_{t} .
$$

That is, the Hledik and Vlsek approach defines neutral interest rate as a function of two stationary variables such as the equilibrium growth of potential GDP and REER.

Stefanski (2018) has a similar approach to the estimation of neutral interest rate by determining the neutral rate from a combination of factors reflecting the impact of potential GDP of the national and world economies. Among the factors of potential GDP Stefanski considers the factors of convergence, investment rates and labor force growth. Stefanski notes that internal factors have a higher impact on the neutral interest rate than external or global factors.

Fonseca and Muinhos (2016), Grafe et al. (2018), and Kuhn et al. (2019) also adapted Laubach and Williams' approach to the open economy conditions.

Other methods for estimating the neutral interest rate used in modern practice include a method based on the dynamic Taylor rule (Basdevant et al., 2004; Magud \& Tsounta, 2012; Duarte, 2010; Ruch, 2021), dynamic (time-varying) autoregression vector (VAR) (Carrillo et al., 2018; Lubik \& Matthes, 2015), uncovered interest parity (UIP) (Magud \& Tsounta, 2012; Grui et al., 2018), consumption elasticity-based models (consumption-smoothing models) and various filtration techniques.

The method for estimating the neutral interest rate based on the dynamic Taylor rule involves the use of the monetary policy equation, where the actual interest rate $\left(i_{t}\right)$ is a function of its neutral level $\left(r_{t}^{*}\right)$, the deviation of expected inflation $\left(\pi_{t}^{e}\right)$ from the target $\left(\pi^{*}\right)$, GDP gap $\left(\hat{y}_{t}\right)$ and shocks $\left(\gamma_{t}\right)$ (Ruch, 2021):

$$
\begin{aligned}
& i_{t}=\tau \cdot i_{t-1}+(1-\tau) \times \\
& \times\left(r_{t}^{*}+\pi^{*}+\alpha \cdot\left(\pi_{t}^{e}-\pi^{*}\right)+\beta \cdot \hat{y}_{t}\right)+\gamma_{t} .
\end{aligned}
$$

The neutral interest rate and the GDP gap are defined as the result of solving a system of equations using the Kalman filter, where the rest of the processes are described as stochastic. In contrast to the Laubach and Williams approach, where the neutral interest rate depends on the development 
of fundamental economic processes, the Taylor rule uses a neutral rate to be largely determined by the central bank's monetary policy parameters needed to achieve macroeconomic balance (keeping inflation at the target level and GDP at a potential level).

Consumption-smoothing models reflect the relationship between supply and demand for loans to households and their willingness to consume over a lifetime (Ruch, 2021). Giammarioli and Valla (2004) argue that such methods are appropriate for large endogenous economies because they ignore the role of money, prices and potential GDP. The method for estimating the neutral interest rate based on the UIP rule (UIP-method) reflects the prioritization of external impact on investment processes in the domestic economy. This is the approach that is used by the National Bank of Ukraine (NBU) (Grui et al., 2018).

The UIP method reflects the balance of internal $\left(i_{t}\right)$ and external $\left(i_{t}^{e x}\right)$ interest rates, taking into account the expected devaluation of the nominal exchange rate $(E)$ under the conditions of free movement of capital (Magud \& Tsounta, 2012):

$$
i_{t}=i_{t}^{e x}+E_{t+1}+\rho_{t},
$$

where $\rho$ - sovereign risk premium.

If in equation (4) the factors are presented in the format of real equilibrium indicators, then the result of its solution will be a real neutral interest rate.

Giammarioli and Valla note that the UIP method for estimating neutral interest rates gives unreliable results in countries with narrow and illiquid financial markets and prove this with the example of countries such as Costa Rica, Dominican Republic, Guatemala, Paraguay, and Uruguay.

At the same time, Grui et al. (2018) indicate that the UIP method is optimal for a small open economy. They define the real neutral rate as a combination of the influence of factors such as the neutral rate in the United States, the sovereign risk premium and the devaluation trend of REER within the semi-structural model of the economy. The drawback of this specification is the lack of a factors that would directly reflect the productivity of the domestic economy. REER, according to the HarrodBalass-Samuelson effect, can indicate a change in productivity only in the long run, while in the medium and short run it is not so (Chong et al., 2012). However, Grui et al. (2018) conceptually do not distinguish between the factors of REER and economic productivity and, therefore, conclude that productivity growth leads to a reduction in the neutral value of money, which contradicts the basic concept of neutral rate in the interpretation of Woodford (2003) and Laubach and Williams (2003), where the demand for money generated by the growth of potential GDP should raise the price of money.

In the latest world practice, research is being conducted on ways to estimate the level of neutral interest rates in a small open economy, which would take into account the impact of factors of domestic demand and domestic savings (Ruch, 2021; Hledik \& Vlcek, 2018; Stefanski, 2018). Ruch (2021), based on model specification in the sample of 30 countries with developing and emerging markets, found that statistically significant factors in the fall of the neutral real interest rate in these countries include a decrease in the growth rates of potential GDP, an increase in life expectancy (increasing savings) and a decrease in the relative cost of capital among production factors.

Regarding the impact of global factors, it is important to highlight the results of studies by Caballero and Farhi (2014), which show that the key factor of the decline in the global neutral interest rate after the 2008 crisis was a new imbalance between savings and the availability of safe assets, that was driven by the stricter requirements of financial regulation.

\section{GENERALIZATION OF MAIN STATEMENTS}

The understanding of key drivers of the neutral interest rate improved with the development of economic theory. However, the basic provision was that changes in savings (supply of funds) and investments (demand for borrowed funds) explain the dynamics of the neutral interest rate as the equilibrium price between supply and demand. 
A key factor in neutral interest rate behavior in the domestic economy is the optimization behavior of households that make consumption or savings decisions based on their own priorities. This affects the aggregate demand and behavior of businesses to invest in production expansion. In the open economy, factors of external demand and the availability of global savings play an important role. Many researchers point out that external factors should be considered in the context of the New-Keynesian model of economics used in the practice of modern monetary policy (Clarida et al., 2002; Bernanke, 2005; Zhu, 2016; Holston et al., 2016). In particular, Ruch (2021), Hledik and Vlcek (2018), and Stefanski (2018) argue that in emerging markets, domestic factors remain dominant in shaping the neutral interest rate trajectory.

The macroeconomic essence of the neutral interest rate within the New-Keynesian model is the certain level of the value of money, when economic processes proceed without the accumulation of imbalances, that is, inflation, real GDP, real exchange rate, unemployment, etc. are close to their equilibrium values (Woodford, 2003; Barsky et al., 2014; Del Negro et al., 2015 and others).

The classic version of the New-Keynesian economic model (Berg et al., 2006) contains four key equations: 1) the interest rate policy rule (Taylor's rule), which determines the level of the key interest rate depending on the neutral interest rate, GDP gap and inflation targeting imbalance; 2) the Phillips equation, which determines inflation being conditional on inflation expectations, GDP gap and REER gap; 3) the equation of aggregate demand (IS curve), which determines the dependence of the GDP gap on interest rate gap and REER gap, and 4) the equation of uncovered interest parity (UIP), where the interest rate of the domestic economy moves in line with the world interest rate, taking into account the parameters of the risk premium and the exchange rate (for countries with small open economies). It means that the neutral interest rate is a part of the Taylor rule and the aggregate demand equation, and can also be directly expressed by the UIP equation.

Summarizing the literature review of methods for estimating the neutral interest rate one can state that at this stage of development of monetary theory no single optimal approach has been proposed.

Approaches based on the Laubach and Williams method (with key factor of potential GDP growth) seem to be theoretically justified, but require complex models. Taylor's rule approaches are simpler, but useless without a high degree of confidence in monetary policy. UIP-based methods require high-quality monetary transmission and omit the impact of internal factors. Consumption-based methods do not take into account global factors and productivity of the domestic economy. Methods based on filtration techniques do not rely on theoretical basis.

These theoretical and methodological problems have direct practical consequences. After all, the value of the neutral interest rate serves as a guide for central bank decisions on monetary policy within the monetary regime of inflation targeting. Depending on the positioning of the key interest rate relative to its neutral level and the current value of the GDP gap, monetary policy will have a "countercyclical" or "procyclical" effect on economic growth (Table 1).

To offset the effects of demand on inflation, the central bank must set the key rate at a level that provides a countercyclical effect on economic growth. This will bring the economy closer to a steady equilibrium state, that is, it will help reduce the GDP gap, restore flexible price equilibrium and full employment.

Mistakes in estimating the neutral rate lead to the following consequences:

Table 1. Matrix of the type of monetary policy

Source: Compiled by the authors.

\begin{tabular}{|c|c|c|c|}
\hline & & \multicolumn{2}{|c|}{ Real GDP } \\
\hline Interest rate gap & & $\begin{array}{c}\text { Below potential } \\
\text { (Negative gap) }\end{array}$ & $\begin{array}{c}\text { Above potential } \\
\text { (Positive gap) }\end{array}$ \\
\hline \multirow{2}{*}{ Key real interest rate } & Above neutral (tight policy) & Countercyclical policy & Pro-cyclical policy \\
\hline & Below neutral (loose policy) & Pro-cyclical policy & Countercyclical policy \\
\hline
\end{tabular}


1) deterioration of the monetary policy's transmission mechanism, when the behavior of bank interest rates on new loans and deposits will not reflect the logic of changes in the key interest rate;

2) pro-cyclical monetary policy, when monetary policy decisions increase the gap between potential and actual GDP, slow down the process of economic recovery after the crisis;

3) difficulty in achieving the inflation target, when non-monetary factors of inflation increase as a result of inadequate political decisions (for example, an increase in the number of bankruptcies may lead to structural gaps in the economy and require the introduction of state price regulation).

Conceptually, the identification of the neutral rate factors mentioned in theoretical sources can be divided into those that affect money demand (potential GDP) and those that affect money supply (savings) (Table 2).

Productivity and economic growth. The neutral interest rate has direct relation to the productivity of the economy and reverse relation to the savings of the economy. A growth in investment reflects the expansion of companies' ability to increase profits, which raises interest rates. High productivity of the economy makes it attractive to domestic and international investors and encourages the latter to be willing to pay more for raising additional capital. An increase in the efficiency of production, in turn, leads to an increase in savings of economic entities, which puts a downward pressure on the neutral interest rate. Indicators of potential GDP, long-term REER trend, consumption and investment dynamics are used to reflect the impact of labor productivity and demand on interest rate.

Savings and convergence. As the countries approach the higher income level, after a stage of intensive productivity growth and meeting the basic needs of society, there comes a period when the growth of savings outpaces the growth of productivity. This promotes a further convergence of economies at higher income levels, which further stimulates the reduction of the neutral interest rate. Productivity is being replaced by new forms of development - ecologization, reduction of inequality, etc. The excess of the supply of savings over the growth of productivity brings about a decrease in the neutral interest rate. Despite the fact

Table 2. Some factors of changes in the neutral interest rate and the type of their influence

\begin{tabular}{|c|c|c|c|}
\hline Money demand factors & Effect & Money supply factors & Effect \\
\hline Growth of total factor productivity in the economy & $\uparrow$ & $\begin{array}{l}\text { Growth of domestic savings due to the expansion of } \\
\text { economic activity }\end{array}$ & $\downarrow$ \\
\hline $\begin{array}{l}\text { Shifting the current priorities of the households in } \\
\text { favor of consumption }\end{array}$ & $\uparrow$ & $\begin{array}{l}\text { Shifting the current priorities of the households in favor of } \\
\text { savings }\end{array}$ & $\downarrow$ \\
\hline Population and labor growth & $\uparrow$ & $\begin{array}{l}\text { Demographic change, population aging, increase in life } \\
\text { expectancy (savings growth factor) }\end{array}$ & $\downarrow$ \\
\hline $\begin{array}{l}\text { Economic boom (causes an increase in demand for } \\
\text { money as the productivity of the economy increases) }\end{array}$ & $\uparrow$ & $\begin{array}{l}\text { Shifting economic policy priorities in favor of supporting } \\
\text { human capital }\end{array}$ & $\downarrow$ \\
\hline $\begin{array}{l}\text { Economic crisis (leads to falling demand for money as } \\
\text { economic productivity decreases) }\end{array}$ & $\downarrow$ & Development of the financial sector & $\downarrow$ \\
\hline $\begin{array}{l}\text { Development of the world economy, intensification of } \\
\text { external demand }\end{array}$ & $\uparrow$ & De-shadowing of the economy & $\downarrow$ \\
\hline Reduction in inequality & $\uparrow$ & Growing global savings & $\downarrow$ \\
\hline $\begin{array}{l}\text { Decrease in the relative cost of raising capital in } \\
\text { comparison with other factors of production }\end{array}$ & $\downarrow$ & $\begin{array}{l}\text { Convergence of economies at higher income levels (savings } \\
\text { growth factor) }\end{array}$ & $\downarrow$ \\
\hline Stricter requirements of financial regulation & $\downarrow$ & $\begin{array}{l}\text { Strengthening of REER due to the inflows of speculative } \\
\text { foreign capital or the surge in world prices for export } \\
\text { goods (short-term trend) }\end{array}$ & $\downarrow$ \\
\hline Reduction of investment risks & $\uparrow$ & $\begin{array}{l}\text { Reduction of the global neutral rate (contributes to } \\
\text { attracting global savings) }\end{array}$ & $\downarrow$ \\
\hline $\begin{array}{l}\text { Emergence of new objects for investing connected } \\
\text { to quality of economic growth (ecologization, human } \\
\text { capital development) }\end{array}$ & $\uparrow$ & Sovereign risk reduction (helps to attract global savings) & $\downarrow$ \\
\hline
\end{tabular}


that savings are a classic factor of the neutral interest rate behavior, their incorporation into the econometric models has not been finalized yet

Demographic changes. The structure and dynamics of the population, changes in the living standards affect both the rate of potential economic growth and the rate of savings. Thus, an increase in the share of middle-aged and elderly people with a higher propensity to save will drive a reduction in the neutral interest rate. At the same time, a contraction in labor supply affects the po tential GD, which also reduces the neutral rate.

The degree of the financial sector development. More developed banking sector and capital market contribute to an increase in the rate of savings in the economy and, as a result, to a decrease in the level of neutral rates. This is facilitated by the lengthening of the planning horizon of economic agents, which increases the importance of the future compared to the present, thereby encouraging increased savings.

A short-term fluctuations in REER may not be in line with its long-term trend. The strengthening of REER due to the expansion of foreign capital increases money supply in the economy and thus reduces the neutral rate (short-term trend). On the other hand, the strengthening of REER due to the growth of labor productivity in the economy and the increase of its external competitiveness (growth of technological exports, etc.) reflects the higher demand for money in the economy and, therefore, put an upward pressure on the neutral interest rate (long-term trend). Since REER does not have a unilateral effect on the neutral rate, its use for estimating the neutral value of money requires more complexity in model specifications.

De-shadowing of the economy contributes to a rise in savings in the official segment of the economy, which predominantly reduces the neutral interest rate.

Reduction in inequality increases the share of the population that can afford more consumer spending (population with a lower marginal propensity to save). This rises the demand for money and the neutral rate.
Factors of economic growth quality. The challenges posed by the crises of 2008-2009 and 20202021 have exacerbated the problem of finding ways to improve the quality of econo mic growth. Increased aggregate demand due to trends in investment in green technologies, human capital, health care, etc. will contribute to growing in demand for money and its neutral value.

Technological progress. A decrease in the relative cost of raising capital (relative to other factors of production) is due to technological progress and reflects the fact that modern investment requires significantly less expenditures on physical assets. Rachel and Smith (2015) estimate that the relative cost of raising capital in today's global economy is $30 \%$ lower than in the 1980s. This factor have downward pressure on the neutral interest rate.

Type of economic policy. The lack or low quality of the social protection system encourages the households. to save more. Laubach (2009) discusses the impact of changes in fiscal policy priorities for the neutral interest rate.

The factors listed in Table 2 are not mutually exclusive and isolated from each other. The same factors can be both the factors of demand for money and the factors of savings (for example, demographic changes, priorities of the population, REER, etc.). Risk premiums can change both the attractiveness of investments and the behavior of households in terms of savings. However, the resulting indicator of the influences of these factors will be the change in potential GDP and the supply of savings, the balance between which determines a neutral level of money value.

In the context of the identified factors affecting the neutral interest rate, the fundamental shortcomings of the UIP-method of its estimation (used by the NBU) are revealed.

The UIP method is based on three assumptions: absolute mobility of capital and labor, absolute interchangeability of national and foreign productive capital, exclusively rational and productive use of capital. Obviously, such an absolutization of free market conditions does not exist in the reality. There are always areas where the supply of goods 
and services cannot be provided by the outside world, there are always irrational losses, and labor mobility has certain limits based on the technological development of society. In addition, countries with low levels of development naturally have problems with the functioning of markets and transmission efficiency, which weakens the opportunities for foreign capital to enter the real sector.

The main drawback of the UIP method is that it does not take into account the imperfection of markets and in fact makes the stability of financing the internal processes of production, redistribution and use of GDP dependent on the situation on the global capital markets. In this context, alternative concepts of neutral interest rate estimation based on the assessment of domestic demand have an advantage - they encompasses both market imperfections and changes in domestic demand for money.

Another problematic aspect of applying the UIP method to measuring the neutral interest rate is associated with the mobility of production factors (labor and capital). The mobility of capital is theoretically unlimited and can be absolute. However, labor mobility is physically restrained. As a result, the elasticity of demand for changes in capital inflows in different countries will vary depending on the flexibility of the labor market and opportunities for labor mobility. Since the demand factor is not taken into account when estimating the neutral interest rate by the UIP method, the neutral rate is determined by default under conditions of equal mobility of labor and capital factors, which doesn't operate in practice.

Another problematic issue in the application of the UIP method is considering the impact of convergence of countries at higher income levels. The purchasing parity rate of the US dollar in Ukraine differs from the market one by 3.6 times. That is, prices in Ukraine expressed in USD are 3,6 times lower than in the United States. At the same time, the level of per capita income in Ukraine is 4,8 times lower than in the United States (IMF, 2021). Trends in both indicators - the "parity exchange rate gap" and the "income gap" - effect the dynamics of convergence of each economy in the process of globalization, and thus determine the level of the neutral interest rate. However, the UIP method only takes into account the real exchange rate factor. Therefore, UIP method doesn't include sufficient factors specification for reflecting economy's convergence.

The use of the UIP method had more advantages in the period before the global crisis of 20082009 , when the process of transforming global capital into the domestic loans was not restrained. After the introduction of new financial regulation, foreign capital markets are no longer able to determine on their own the neutral value of money in the domestic economy. Under such conditions, failure to take into account the internal factors of economic development involve the risk of incorrect specification of monetary policy in relation to the current phase of the economic cycle.

Currently, the only advantage of the UIP method is its relative simplicity and ease of integration with DSGE-type models. Given the numerous drawbacks of the UIP method for small open economies, it is more appropriate to use the Laubach and Williams (2016) approach in the extended specification, with inclusion of the external factors. This will allow an objective assessment of changes in the neutral value of money, taking into account the impact of changes in economic productivity or the supply of domestic savings.

\section{DISCUSSION}

The 2020-2021 crisis has clearly demonstrated the shortcomings of the tools for estimating the neutral interest rate developed by monetary theory and practice.

Holston et al. (2020) concluded that the Laubach and Williams (2003) method is too simplified for measuring a neutral interest rate during a pandemic, given the extraordinary nature of the crisis and policy measures. At the same time, these authors suggest that a neutral interest rate will be kept low in the foreseeable future, and the Laubach and Williams model will remain a useful tool for analyzing the effects of the pandemic.

The coronavirus crisis has led to a general decline in aggregate domestic demand and real sector profitability, which has significantly reduced the 
Source: Compiled by the authors based on the NBU and State Statistics Service of Ukraine data.

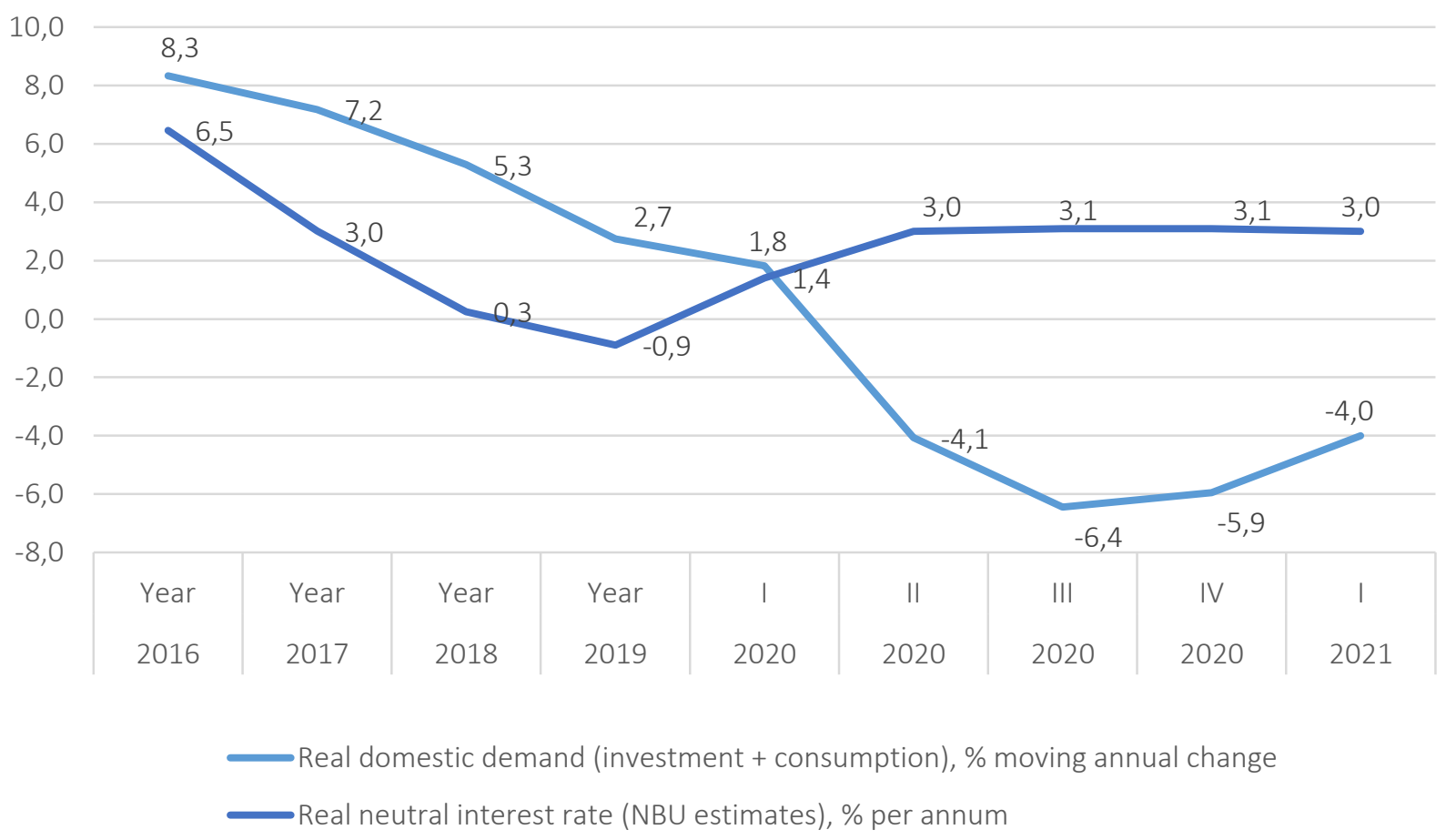

Figure 1. Neutral interest rate and domestic demand in Ukraine

demand for money. At the same time, there has also been an increase in savings everywhere (due to expansionary government policies and physical constraints on consumer spending). Banking systems received an additional inflow of deposits due to intensified processes of forced digitalization of economic relations and the associated de-shadowing, as well as the forced spending of accumulated cash savings in foreign currency. The falling demand for money and the increase in the money supply have fundamentally reduced the neutral value of money, accelerating the existing impulses from the aging population, stagnation of the world economy, and much more.

The vast majority of methodological approaches to estimating the neutral interest rate doesn't incorporate the factor of domestic savings, which are considered either among other factors or not accounted at all, following the logic that changes in savings are constant or elastic to changes in aggregate demand. The realities of the current crisis have shown that this may not be the case. In addition, phenomena such as inequality, age-related changes in the population structure make cause shifts in the trend of savings. Therefore, the savings factor, along with poten- tial demand, needs to be separately included into the equations or models devised for the neutral interest rate estimation.

UIP method for estimating the neutral interest rate reflects even greater inadequacy to changes in economic conditions, as it does not take into account domestic determinants of interest rate. Since the UIP method considers only those factors that indicate the external attractiveness of the economy, the COVID-related factors of neutral interest rate movements cannot be captured by this method.

The inadequacy of the UIP method can be illustrated by the example of Ukraine, where such methodology are employed by the NBU within the framework of a semi-structural model based on New-Keynesian theory (Grui et al., 2018).

As Figure 1 shows, in the period of relative stability in 2016-2019 the trends in the neutral interest rate and domestic demand moved in parallel. A decline in the neutral rate was influenced by the reduction in the risk premiums and the real strengthening of Hryvnia exchange rate. However, the situation has changed since the first quarter 
Source: Compiled by the authors based on the NBU, the State Statistics Service of Ukraine, and the Federal Reserve Bank of New York data.

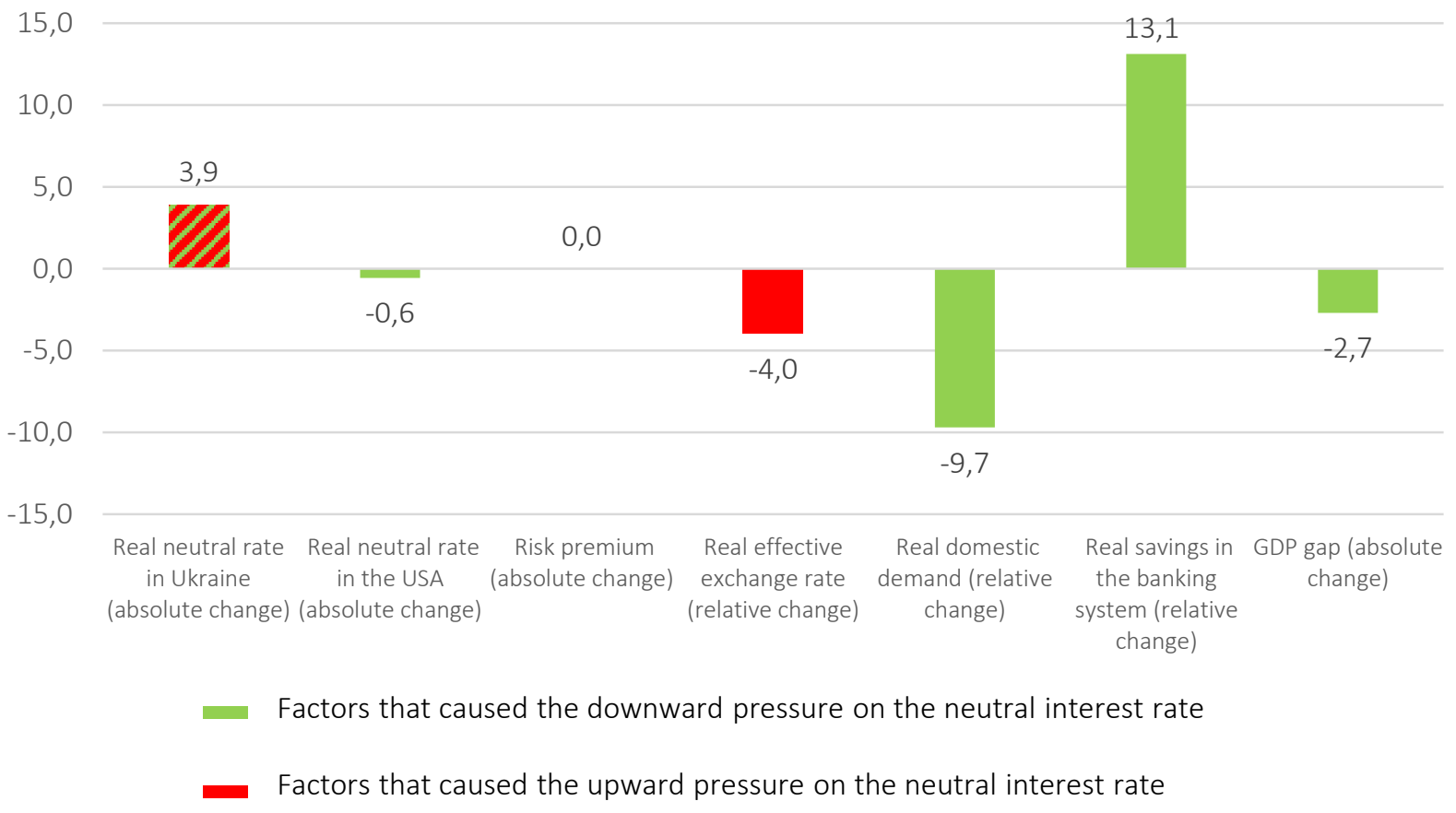

Figure 2. Change in the neutral interest rate and its factors in Ukraine (first quarter of 2021 compared to 2019)

of 2020. Domestic demand fell sharply (primarily due to falling investment activity), but neutral interest rate estimates, on the contrary, were raised (solely due to expectations of devaluation of Hryvnia's REER).

Figure 2 shows that the changes in demand and domestic bank savings (factors lowering the neutral interest rate) were more significant than the impulse from the devaluation of REER (the factor increasing the neutral interest rate). However, the first effects were not considered at all in the estimates of Ukraine's neutral rate, undertaken by NBU.

During the coronavirus pandemic, researchers from central banks of other countries revised the estimates of neutral interest rates downwards: in Russia - by 1 percentage point (The Central Bank of the Russian Federation, 2020), Canada - by 0,5 percentage points (Bank of Canada, 2020), and the USA - by 0,6 percentage points (The Federal Reserve Bank of New York, n.d.). At the same time, the NBU in 2020 increased the real neutral interest rate estimates for Ukraine by 3,9 percentage points (NBU, 2021).
The overestimation of Ukraine's neutral interest rate has already brought about important consequences in terms of monetary policy. From March to July 2021 the NBU raised the key policy rate by 200 basis points from 6 to $8 \%$ per annum under the growing inflation pressure. According to the regulator's logic, such an increase should have redirected part of the household's income from consumption needs to savings purposes and modified inflation expectations. At the same time, monetary policy should remain neutral or soft, as the nominal neutral interest rate (real neutral interest rate + inflation target) was estimated by the NBU at about $8.0 \%$ per annum (NBU, 2021). However, actually, as the real neutral value of money (taking into account the effects of domestic factors) was much lower, the reaction of deposit and loans' interest rates was the exact opposite to the NBU's expectations, that is, they continued to decline following the fundamental downward trend in the neutral value of money in the economy. At the beginning of August 2021, a new monetary phenomenon appeared - the NBU key policy rate exceeds the interest rates on time deposits obtained by banks from individuals (Figure 3). 


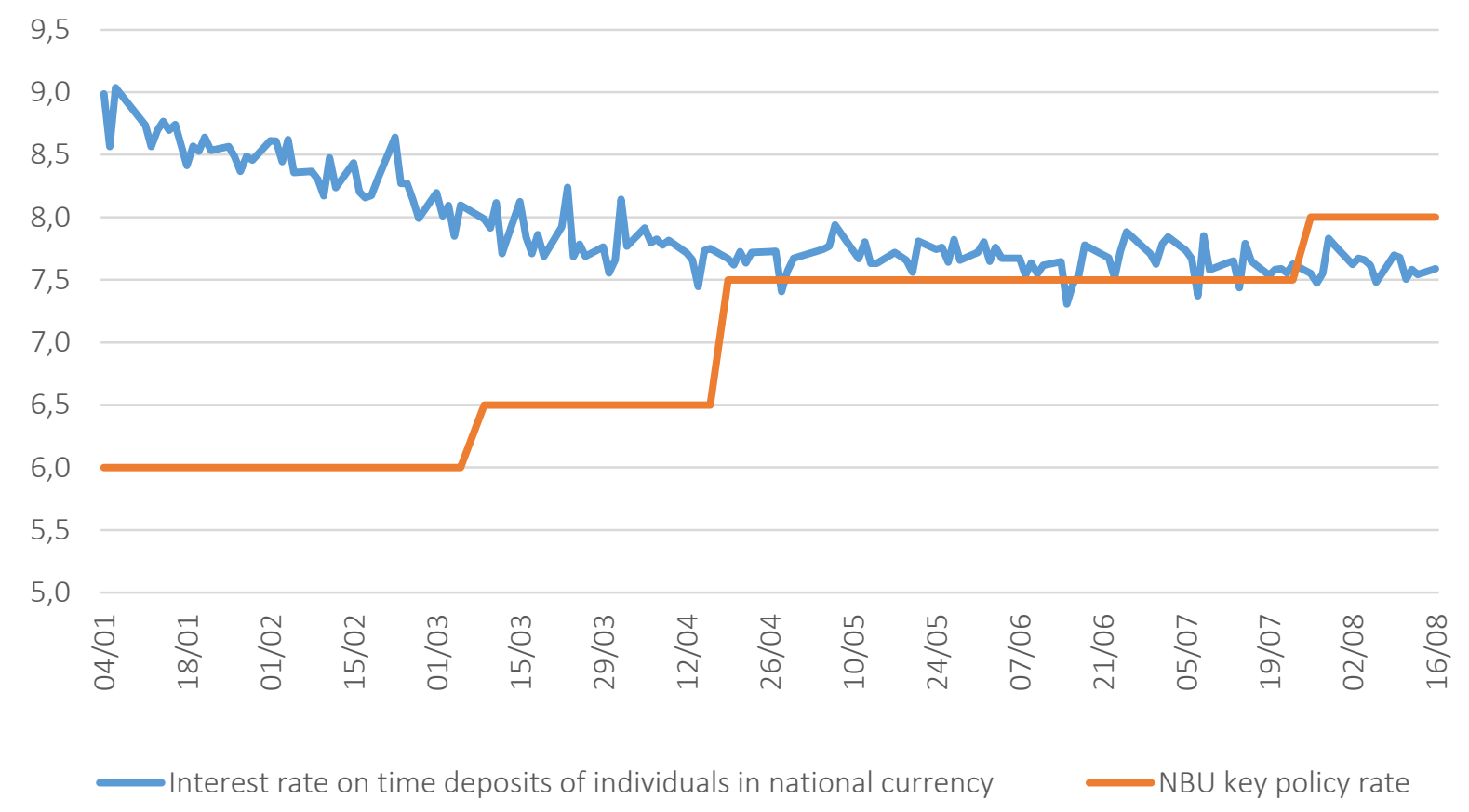

Figure 3. NBU key policy rate and interest rates on deposits, $\%$ per annum

In other words, the increase in the central bank key policy rate weakened the transmission of interest rates and widened macroeconomic imbalances, as monetary policy became restrictive and pro-cyclical in time of ongoing economic crisis.

UIP method assumes that the global savings can effectively cover the lack of domestic savings and rise the productivity of domestic economy (Perrelli \& Roache, 2014; Grui et al., 2018). In many cases inflows of global saving are associated with higher returns on invested capital. The UIP rule equates the value of money in the economy with its value in the world markets, taking into account the risk premium. However, if the productivity of the real sector of the domestic economy is unable to provide the desired return for foreign investors, the inflow of foreign capital will be concentrated in specific areas that weakly affect the overall economic productivity (such as lending to domestic government or consumer import lending, i.e.). As a result, the interest rate on attracting foreign capital will remain permanently high (due to the persistence of high risks in the real sector), but the productivity of the economy and its potential GDP will not increase.

In any case, the world economy is not able to completely replace domestic production of goods and services, some of which will always be exclusively local in nature, forming domestic demand and supply of money. Therefore, the determination of the domestic neutral interest rate in accordance with the trends of world markets will not be relevant to reflect the demand and supply of money.

In Ukrainian economy period of 2017-2019 was quite favorable for foreign investors the key interest rate was high (13-18\% per annum) and REER was strengthening. The country had a lack of national savings and investments (gross capital formation fell less 15\% of GDP in 2019). Inflow of foreign investments exceeded 30 billion dollars (in 2017-2019), but only 15\% of them represented the direct investments into the equity and investment fund shares of enterprisers (only 4,7 billion dollars or $1,2 \%$ of GDP). The remaining foreign investments (85\% of total) were directed to financial assets, debt capital, or took the form of reinvested earnings of existing companies (NBU, n.d.). The share of foreign investors among sources of financing investments in fixed capital fell below 1\%! (State Statistics Service of Ukraine, n.d.). Therefore, there was no effective replacement of domestic saving with foreign capital inflows. 
This confirms the need to improve the tools for assessing the neutral interest rate for both endogenous economies and countries with small open economies.

The task for the future research is to develop the tools of the neutral interest rate estimation towards expanding the internal factors of demand for money (productivity, changes in the number and structure of labor, changes in the relative cost of raising capital), as well as to identify separately the factor of domestic savings (taking into account demographic trends), intertemporal priorities of the households, de-shadowing). At the same time, the feasibility of using the REER factor in the models for neutral interest rate estimation is questionable.

A separate aspect of improving the methodological tools of the neutral interest rate is taking into account demand factors related to inclusive growth - a trend to improve the quality of economic growth, which is gaining popularity in the world economy and is supported by international organizations. Components of demand for money, such as investment in the "green" economy or human capital, can push the trend of the neutral interest rate upward.

\section{CONCLUSION}

Based on the generalization of methods employed in world practice for measuring the neutral interest rate, the following provisions were derived:

- neutral interest rate estimates are of key importance for the implementation of a balanced and sound monetary policy of central banks operating under the inflation targeting regime;

- in the economic literature and international practices, there is no single generally accepted theoretical and methodological approach to specification and estimation of the neutral interest rate; moreover, approaches that are appropriate for application in economies with endogenous forces of development are not advisable to be used in the small open economies;

- the classical interpretation of the neutral interest rate involves its estimation based on the balance between supply and demand of money. However, the complexity of the application of such a concept entails the fact that in the practice those methods are used that give preference to certain factors such as potential GDP, private consumption, external factors, etc.;

- the most common method for estimating the neutral interest rate is the Laubach and Williams method in different variations, which takes into account changes in potential GDP, household savings and other factors;

- the main debatable issue in measuring the level of the neutral interest rate is the relationship between the impact on it of internal and external factors. Internal factors reflect changes in the productivity of the economy, and external reflect the availability of global savings and the impact of the world economy on aggregate demand.

The COVID-19 pandemic and economic crisis highlight the shortcomings of certain methods for estimating the neutral interest rate. It is established that the most problematic method for estimating the neutral interest rate is the UIP method (used by the NBU), which is based solely on the external investment attractiveness of the national economy and does not take into account changes in domestic demand for money and changes in domestic savings. This hypothesis is supported by Ukraine's statistical data for 2020-2021, as well as by the results of research by experts from other central banks (in particular, the Czech Republic and Polish banks). 
The results obtained put a basis for conclusion about the need to modify the methodology for estimating the neutral interest rate used in Ukraine - with the development of a model apparatus based on the key findings of Laubach and Williams and modifying the specification of equations to include external factors.

Basic methodological pillars have been developed for the improvement of neutral interest rate estimation, which are based on a new vision of the role of monetary policy and central bank activity on the whole in achieving the goals of inclusive economic growth and sustainable development. They cover the issues of domestic demand for money, which should be measured taking into account investments in social capital, green economy, etc., as well as money supply issues, which should take into account, among other things, the dynamics of demographic changes or life expectancy shifting the priorities of the population from consumption to savings.

\section{AUTHOR CONTRIBUTIONS}

Conceptualization: Bohdan Danylyshyn.

Data curation: Bohdan Danylyshyn, Ivan Bohdan.

Formal analysis: Bohdan Danylyshyn, Ivan Bohdan.

Funding acquisition: Bohdan Danylyshyn.

Investigation: Bohdan Danylyshyn, Ivan Bohdan.

Methodology: Bohdan Danylyshyn, Ivan Bohdan.

Project administration: Bohdan Danylyshyn.

Resources: Ivan Bohdan.

Software: Ivan Bohdan.

Supervision: Bohdan Danylyshyn, Ivan Bohdan.

Validation: Bohdan Danylyshyn.

Visualization: Ivan Bohdan.

Writing - original draft: Bohdan Danylyshyn, Ivan Bohdan.

Writing - review \& editing: Bohdan Danylyshyn.

\section{REFERENCES}

1. Bank of Canada. (2020). The neutral rate in Canada: 2020 update, 2020-24. Retrieved from https://www.bankofcanada.ca/ wp-content/uploads/2020/10/ san2020-24.pdf

2. Barsky, R., Justiniano, A., \& Melosi, L. (2014). The Natural Rate of Interest and Its Usefulness for Monetary Policy. American Economic Review, 104(5), 37 43. https://doi.org/10.1257/ aer.104.5.37

3. Basdevant, O., Bjorksten, N., \& Karagedikli, O. (2004). Estimating a Time Varying Neutral Real Interest Rate for New Zealand (Reserve Bank of New Zealand Discussion Paper Series, 2004/01). Retrieved from https://www.rbnz.govt.nz/-/ media/ReserveBank/Files/Publica-
tions/Discussion\%20papers/2004/ dp04-01.pdf?revision $=7 \mathrm{~b} 2519 \mathrm{df}$ 79fc-4a19-aa0e-935c0d53d74e

4. Behera, H., Pattanaik, S., \& Kavediya, R. (2017). Natural Interest Rate: Assessing the Stance of India's Monetary Policy Under Uncertainty. Journal of Policy Modeling, 39(3), 482-498. https://doi.org/10.1016/j.jpol$\bmod .2017 .03 .002$

5. Berg, A., Karam, P., \& Laxton, D. (2006). Practical Model-Based Monetary Policy Analysis - A How-To Guide (IMF Working Paper, 06/81). https://doi. org/10.5089/9781451863413.001

6. Bernanke, B. (2005). The Global Saving Glut and the U.S. Current Account Deficit. The Federal Reserve Board. Retrieved from https://www.federalreserve.gov/boarddocs/speeches/2005/200503102/default.htm

7. Caballero, R., \& Farhi, E. (2014). On the Role of Safe Asset Shortages in Secular Stagnation. Retrieved from https://voxeu.org/article/ role-safe-asset-shortages-secularstagnation

8. Carrillo, J., Elizondo, R., Rodríguez-Pérez, C., \& Roldán-Peña, J. (2017). What Determines the Neutral Rate of Interest in an Emerging Economy? (Banco de México Working Papers, 201822). Retrieved from https://www. banxico.org. $\mathrm{mx} /$ publications-andpress/banco-de-mexico-workingpapers/\%7BDB137D03-30CE8C9A-1BBD-52C4EEE3BE29\%7D. pdf 
9. Central Bank of the Russian Federation (2020). Monetary Policy Report, July 2020. Retrieved from https://www.cbr.ru/eng/about_br/ publ/ddkp/longread_3_31/page/

10. Chong, Y., Jordà, O., \& Taylor, A. (2012). The Harrod-BalassaSamuelson Hypothesis: Real Exchange Rates and their Longrun Equilibrium. International Economic Review, 53(2), 609-33. https://doi.org/10.1111/j.14682354.2012.00694.x

11. Clarida, R., Gali J., \& Gertler M. (2002). A Simple Framework for International Monetary Policy Analysis. Journal of Monetary Economics, 49(5), 879-904. https://doi.org/10.1016/S03043932(02)00128-9

12. Del Negro, M., Giannoni, M., \& Schorfheide, F. (2015). Inflation in the Great Recession and New Keynesian Models. American Economic Journal: Macroeconomics, 7(1), 168-196. https://doi. org/10.1257/mac.20140097

13. Duarte, J. (2010). Measuring the Natural Interest Rate in Brazil. Institute of Brazilian Business and Public Management Issues. Spring 2010. Retrieved from https:// nanopdf.com/download/measuring-the-natural-interest-rate-inbrazil_pdf\#

14. Federal Reserve Bank of New York. (n.d.). Measuring the Natural Rate of Interest. Retrieved from https:// www.newyorkfed.org/research/ policy/rstar

15. Fonseca, M., \& Muinhos, M (2016). Equilibrium Interest Rates in Brazil: a Laubach and Williams Approach Retrieved from https:// hdl.handle.net/10438/29420

16. Giammarioli, N., \& Valla, N. (2004). The natural real interest rate and monetary policy: a review. Journal of Policy Modeling, 26(5), 641-660. https://doi.org/10.1016/j. jpolmod.2004.01.007

17. Grafe, C., Grut, S., \& Rigon, L. (2018). Neutral Interest Rates in CEEMEA-Moving in Tandem with Global Factors. Money and Finance, 77(1), 6-25. https://doi. org/10.31477/rjmf.201801.06

18. Grui, A., Lepushynskyi, V. \& Nikolaychuk, S. (2018). A Neutral
Real Interest Rate in the Case of a Small Open Economy: Application to Ukraine. Visnyk of the National Bank of Ukraine, 243, 4-20. https://doi.org/10.26531/ vnbu2018.243.004

19. Hledik, T., \& Vlcek, J. (2018) Quantifying the Natural Rate of Interest in a Small Open Economy - The Czech Case (Working Paper Series of the Czech National Bank, 7/218). Retrieved from https:// www.cnb.cz/export/sites/cnb/ en/economic-research/.galleries/ research_publications/cnb_wp/ cnbwp_2018_07.pdf

20. Holston, K., Laubach, T., \& Williams, J. (2016). Measuring the Natural Rate of Interest: International Trends and Determinants (Finance and Economics Discussion Series, 2016-073). http://dx.doi.org/10.17016/ FEDS.2016.073

21. Holston, K, Laubach, T., \& Williams, J. (2020). Adapting the Laubach and Williams and Holston, Laubach, and Williams Models to the COVID-19 Pandemic. Retrieved from https://www.newyorkfed.org/medialibrary/media/ research/policy/rstar/LW_HLW COVID_note

22. Humala, A., \& Briones, G. (2009). Estimation of a Time Varying Natural Interest Rate for Peru (Serie de Documentos de Trabajo Working Paper series, 2009-009). Retrieved from https://ideas.repec. org/p/rbp/wpaper/2009-009.html

23. International Monetary Fund. (2021). World Economic Outlook Database, April 2021. Retrieved from https://www.imf.org/en/ Publications/WEO/weo-database/2021/April

24. Kuhn, L., Ruch, F., \& Steinbach, R. (2019). Reaching for the (r)stars: estimating South Africa's neutral real interest rate (South African Reserve Bank Working Paper Series, 19/01). Retrieved from https://www.resbank.co.za/ content/dam/sarb/publications/ working-papers/2019/9097/WP1901.pdf

25. Laubach, T. \& Williams, J. (2003). Measuring the Natural Rate of Interest. The Review of Economics and Statistics, 85(4), 1063-1070. Retrieved from http://www.jstor. org/stable/3211826

26. Laubach, T., \& Williams, J. (2016) Measuring the Natural Rate of Interest Redux. Business Economics, 51(2), 57-67. https://doi. org/10.1057/be.2016.23

27. Laubach, T. (2009). New Evidence on the Interest Rate Effects of Budget Deficits and Debt. Journal of the European Economic Association, 7(4), 858-885. https://doi. org/10.1162/JEEA.2009.7.4.858

28. Lubik T. \& Matthes C. (2015). Calculating the Natural Rate of Interest: A Comparison of Two Alternative Approaches (Federal Reserve Bank of Richmond, Economic Brief, 15-10). Retrieved from https://www.richmondfed. org/-/media/richmondfedorg/ publications/research/economic brief/2015/pdf/eb_15-10.pdf

29. Magud, N., \& Tsounta, E. (2012). To Cut or Not to Cut? That is the (Central Bank's) Question in Search of the Neutral Interest Rate in Latin America (IMF Working Paper, 12/243). https://doi. org/10.5089/9781475512502.001

30. National Bank of Ukraine. (2021). Inflation Report, April 2021. Retrieved from https://bank.gov.ua/ admin_uploads/article/IR_2021Q2_eng.pdf?v=4

31. National Bank of Ukraine. (n.d.). Official web-site. Retrieved from https://bank.gov.ua

32. Ogunç, F., \& Batmaz, I. (2011). Estimating the Neutral Real Interest Rate in an Emerging Market Economy. Applied Economics, 43(6), 683-693. https://doi. org/10.1080/00036840802599768

33. Perrelli, R., \& Roache, S. (2014). Time-Varying Neutral Interest Rate - The Case of Brazil (IMF Working Paper, 14/84). https://doi. org $/ 10.5089 / 9781484385210.001$

34. Rachel, L. \& Smith, T. (2015). Secular Drivers of the Global Real Interest Rate (Bank of England, Staff Working Paper, No. 571). Retrieved from http:// www.centreformacroeconomics. ac.uk/Discussion-Papers/2016/ CFMDP2016-05-Paper.pdf 
35. Ramsey, F. (1928). A Mathematical Theory of Saving. The Economic Journal, 38(152), 543-559. https://doi.org/10.2307/2224098

36. Ruch, F. (2021). Neutral Real Interest Rates in Inflation Targeting Emerging and Developing Economies (World Bank Policy Research Working Paper, 9711). https://doi. org/10.1596/1813-9450-9711

37. State Statistics Service of Ukraine. (n.d.). Official web-site. (In Ukrainian). Retrieved from http://www. ukrstat.gov.ua

38. Stefanski, M. (2018). Natural Rate of Interest in a Small Open
Economy with Application to CEE Countries. Retrieved from https:// www.nbp.pl/badania/konferencje/2018/summer/papers/11_ Stefanski_M.pdf

39. Wicksell, K. ([1898] 2007). Interest and Prices (240 p.). The Ludwig von Mises Institute, Auburn, Alabama. Retrieved from https://books.google.com.ua/ books?hl=ru\&lr $=\& i d=2 \ldots$ gvXM kULEC\&oi=fnd\&pg=PR7\&ots $=$ m4c7jOeT8L\&sig=hNhvYE_CXtEiOtjybB20E7_Ogk8\&redir_ $\mathrm{esc}=\mathrm{y} \# \mathrm{v}=$ onepage $\& \mathrm{q} \& \mathrm{f}=$ false
40. Wicksell, K. (1907). The Influence of the Rate of Interest on Prices. The Economic Journal, 17(66), 213-220. https://doi. org/10.2307/2220665

41. Woodford, M. (2003). Interest and prices: Foundations of a theory of monetary policy (808 p.). Princeton, N.J.; Woodstock, Oxfordshire: Princeton University Press.

42. Zhu, F. (2016). Understanding the changing equilibrium real interest rates in Asia-Pacific. BIS Working Papers, 567. Retrieved from https://www.bis.org/publ/work567. pdf 